\title{
Special issue of Matériaux et Techniques devoted to SAM-12
}

\author{
Jean-Pierre Birat ${ }^{\mathrm{a}}$ \\ IF Steelman, Semécourt, France
}

Received: 28 February 2019 / Accepted: 28 February 2019

The 12th edition of the Society and Materials conferences, SAM-12, took place in Metz, France from 23 to 24 May, 2018. This special issue of Matériaux et Techniques collects 9 papers presented during this meeting. These papers can be regarded as highlights of the conference, in as far as they deal with some of the main topics that were discussed during these two days.

SAM conferences are dedicated to the exploration of the interdisciplinary boundaries related to materials and their connection with society, the environment and nature. They try to analyze how anthroposphere, biosphere and geosphere interact. They propose new approaches, new methodologies and act as a laboratory for new thinking in the area.

One boundary between the spheres is related to Materials and Social Sciences and Humanities (SSH):

- the paper by Jean-Pierre Birat explores the matter of environmental ethics, which is the contribution of ethics and philosophy for fleshing out the concepts of sustainable development, which the material community has adopted wholeheartedly, of the circular economy, of the responsibilities for pollution, of the nature of pollution, etc. [1];

- Michael Kohlgrüber et al. [2] discuss the topic of social innovation and show how impowering the future users of a new technology in the workplace to engage in process innovation accelerates its implementation and its timeto-market. It also speeds up the Social Life-Cycle of that particular innovation (the concept is defined in the previous paper).

Another boundary is related to Materials and policymaking, activism and strategic, geopolitical analysis, i.e. to politics:

- thus, Romain Allais and Julie Grobert [3] explore systemic change, which other would call technological breakthroughs or paradigm shifts, in order to deal with the extreme danger to nature that human activities pose in the 21st century;
- in a slightly different register, Volodymyr Shatokha explores how development and environmental challenges question the future of the steel industry in Ukraine [4].

Saicha Gerbinet et al. deal with the effect of heavy metals on human toxicity, another boundary between biosphere and anthroposphere, as far as Life is concerned [5]. They do it in the framework of $L C A$ and in connection with agricultural production and show how the methodology introducing toxicology in LCA is still difficult to use and may easily lead to the wrong conclusions regarding the nocivity of some particular toxicant.

Another paper, by Nathanael Ko et al. explores the limits of LCA in the case of space debris, generated at the end of life of satellites and other spacecrafts [6]. What kind of impact ought to be defined? When is a threshold reached for a Kessler syndrome, i.e. the situation when debris become so numerous that a collision will cause a catastrophic series of more collisions?

Next comes a set of papers, which discuss the fate of the minor elements in metals flows, elements which are usually overlooked. They explore how to take this matter into account through MFA methodology. Thus, Kenichi Nakajima et al. on one hand [7] and Zhengyang Zhang et al., on the other hand [8], stress the point that the best way to make sure rare elements are reused in the economy is no so much recycling per se, but the remanufacturing of the goods which include them. The flow analysis is carried out using the MaTrace-alloy model, but practical solutions to extend the life of goods are also explored.

A final paper by Colla et al. shows a practical application of energy optimization to reduce environmental impact in a steel mill, by managing its internal gas resources in a subtle way [9].

As a complement to the selected papers published in this issue, the complete program of the conference is found in Appendix A.

\footnotetext{
${ }^{\mathrm{a} C h a i r m a n}$ of the scientific committee of SAM conferences
} 


\section{Appendix A: : Supplementary material 12th Society And Materials International Conference,}

SAM 12, Metz 22-23 May, 2018

Day 1-22 May 2018

Welcome address - Pierre CHEVRIER, ENIM, JeanPierre BIRAT, IF Steelman, France

Keynote Lecture: energy and materials in the low carbon transition: scarcity or abundance?, Patrick CRIQUI, CNRS, France

Session 1: Sustainability in practice, eco-design and new business models

Chairman: Patrick CRIQUI, CNRS, France

- Assessing the efficiency of the off-gas network management in integrated steelworks, V. Colla, Scuola Superiore Sant'Anna, Italy;

- SMEs and eco-design: how to deploy massively, S. Mayer, Pôle éco-conception, France;

- Integration of sustainability in research and innovation: perspectives from ArcelorMittal's Experience, A.-L. Hettinger, ArcelorMittal R\&D, France;

- Life Cycle Assessment of a Carsharing Product-Service System, O. Guyon, PSA, France;

- Sustainable Business Models \& Life Cycle Assessment: Leasing of Steel Sheet Piles, R. Turconi, ArcelorMittal R\&D, France.

Session 2: Social sciences and materials Italy

Chairman: Andrea Declich, Knowledge \& Innovation,

Keynote lecture: opportunities and limits of the Circular Economy - A metallurgical perspective, Markus REUTER, University of Freiberg, Germany

- How Product Social Impact Assessment (PSIA) differs from Product Social Value Assessment (PSVA) and why they complement each other, M. Caraty \& J.P. Chanteau, ArcelorMittal R\&D / Université Grenoble Alpes, France;

- A new innovation paradigm: Combining technological and social innovation, A.Schroeder, TU Dortmund, Germany;

- Approaching the "Human Factors" in Formation of Industrial Symbiosis, H. Fyhn, NTNU, Norway;

- Social cycle of materials and collective actors: Some ideas for analysis, A. Declich, Knowledge \& Innovation, Italy;

- LCA-based calculation of the added value of products: Case study of a concentrated solar power plant, N. Ko, University of Stuttgart, Germany;

- Societal Life Cycle Impact Assessment framework for potential job creation and case study on the French carbon fiber aeronautical recycling sector, A. Thevenot, université de Bordeaux, France.

Session 3a: LCA, MFA and new methodologies

- End of life of wind energy systems: a regional case study, N. Tazi, CREIDD, France;

- Impact of heavy metals on human toxicity using LCA: a case study for walloon corn, S. Gerbinet, university of Liège, Belgium;
- Emergy analysis of biogas production using a life cycle inventory approach, A. Marvuglia, LIST, Luxemburg;

- End of life scenarios for construction materials: a case study from a Luxembourgish Eco-Village, A. Bolowich, LIST, Luxemburg.

\section{Day 2-23 May 2018}

Session 3b: LCA, MFA and new methodologies Chairman: Réjean Samson, CIRAIG, Canada

Keynote lecture: EIT raw materials and circular economy, Ignacio Calleja, EIT-Raw Materials, Germany

- Phosphorus and nitrogen management in Austria as an example for the benefits of coupled resource analysis, J. Tanzer, TU Wien, Austria;

- (Im-)Material flow analysis for system innovation, J. Gobert, ENPC/INSA Strasbourg, France.

Session 4: circular economy, beyond the hype

Chairman: Ignacio Calleja, EIT-Raw Materials, Germany

Keynote lecture: the environment, from the standpoints of philosophy and social sciences, Jean-Pierre Birat, IF Steelman, France

- a dynamic vs an attributional LCA to stimulate circular economy in the construction sector: new construction materials from industrial waste, K. Van acker, KU Leuven, Belgium;

- VALDEM project: from LCA of demolition waste to circular economy of buildings, S. Groslambert, university of Liège, Belgium;

- Decoupling evaluation using total material requirement and life-cycle $\mathrm{CO}_{2}$ emissions, E. Yamasue, Ritsumeikan university, Japan;

- An estimation of the amount of dissipated alloy elements in special steel from automobile recycling processes, Z. Zhang, Tohoku university, Japan;

- Closing the loop on platinum from catalytic converters: contributions from material flow analysis, M. Saidani, Centrale Supelec, France.

Session 5: E-mobility, electrification of energy and energy storage

Chairman: Jean-Pierre Birat, IF Steelman, France

Keynote lecture: which innovation for a sustainable future, Luc Chefneux, Royal Academy of Belgium, Belgium

- Stationary battery systems: recyclability and the life cycle impact on the depletion of mineral resources, J.Peters, KIT, Germany;

- Use phase simulation for the environmental evaluation of electrified vehicle's traction batteries, J. Garcia, PSA, France;

- Smart, sustainable \& resilient - how electric vehicles affect the infrastructures and resources demand of cities, S. Ziemann, KIT, Germany;

- Investigating energy storage systems use phase, H. Elzein, CIRAIG, Canada;

- Using dynamic energy and material flow analysis for assessing the potential of circular approaches to reduce resource criticality, A. Regett, FfE e.V., Germany;

- Batteries for stationary grid application - potential resource demand until 2050, M. Weil, KIT, Germany. 


\author{
SAM 10 Conclusions - Jean-Pierre Birat, IF Steel- \\ man
}

\section{Posters}

- Development of impact categories for the application of LCA in Space - Space Debris, N. KO, University of Stuttgart, Germany;

- Environmental impact assessment of freight transport in three Belgian scenarios in the year 2030, S. Groslambert, University of Liège, Belgium;

- Development of multi-value circulation based on remanufacturing, K. Nakajima, NIES, Japan;

- Industrial symbiosis performance assessment in integrated iron and steel plants using the System dynamics approach, R. Norbert, ArcelorMittal, France;

- One year of varied use of clothing: sustainability through renting? F. Piontek, Ulm university, Germany;

- Ukraine's commitments under association agreement: challenges and opportunities for steel industry, V. Shatokha, National Metallurgical Academy of Ukraine, Ukraine;

- Comparison of material flow analysis between Canada and France: the impact of mining on an economic system, A. Thevenot, University of Bordeaux, France;

- Environmental evaluation of waste management options of secondary batteries in developing countries, M. Weil, KIT, Germany;

- Life cycle thinking as a future guidance for recycling technologies and raw materials, R. Graf \& F. Gehring, Fraunhofer Institute for Building Physics, Germany;

- In-use wood-based materials stock in Indonesia: a dynamic material flow analysis, R. Aryapratama, University of Freiburg, Germany;

- Education of students and citizens for new materials, A. Delebarre, Mines ParisTech, France.

\section{References}

1. J.-P. Birat, The environment and materials, from the standpoints of ethics, social sciences, law and politics, Matériaux \& Techniques 106, this special issue (2018)

2. M. Kohlgrüber, A. Schröder, F. Bayón Yusta, A. Arteaga Ayarza, A new innovation paradigm: combining technological and social innovation, Matériaux \& Techniques 106, this special issue (2018)

3. R. Allais, J. Gobert, (Im-)material flow analysis for system innovation, Matériaux \& Techniques 106, this special issue (2018)

4. V. Shatokha, Ukraine's commitments under association agreement: challenges and opportunities for steel industry, Matériaux \& Techniques 106, this special issue (2018)

5. S. Gerbinet, F. Van Stappen, S. Belboom, E. Pezennec, A. Léonard, Impact of heavy metals on human toxicity using LCA: the case study of walloon corn,Matériaux \& Techniques 106, this special issue (2018)

6. N. Ko, R. Bouslama, T. Betten, S. Pfeuffer, Fundamentals for the development of impact categories for the application of LCA in space - space debris, Matériaux \& Techniques 106, this special issue (2018)

7. K. Nakajima, M. Matsumoto, H. Murakami, M. Hayakawa, Y. Matsuno, W. Takayanagi, Development of multi-value circulation based on remanufacturing, Matériaux \& Techniques 106, this special issue (2018)

8. Z. Zhang, K. Takeyama, H. Ohno, K. Matsubae, K. Nakajima, T. Nagasaka, An estimation of the amount of dissipated alloy elements in special steel from automobile recycling, Matériaux \& Techniques 106, this special issue (2018)

9. V. Colla, I. Matino, S. Dettori, A. Petrucciani, A. Zaccara, V. Weber, S. Salame, N. Zapata, S. Bastida, A. Wolff, R. Speets, L. Romaniello, Assessing the efficiency of the off-gas network management in integrated steelworks, Matériaux \& Techniques (2018)

Cite this article as: Jean-Pierre Birat, Special issue of Matériaux et Techniques devoted to SAM-12, Matériaux \& Techniques 107, $101(2019)$ 